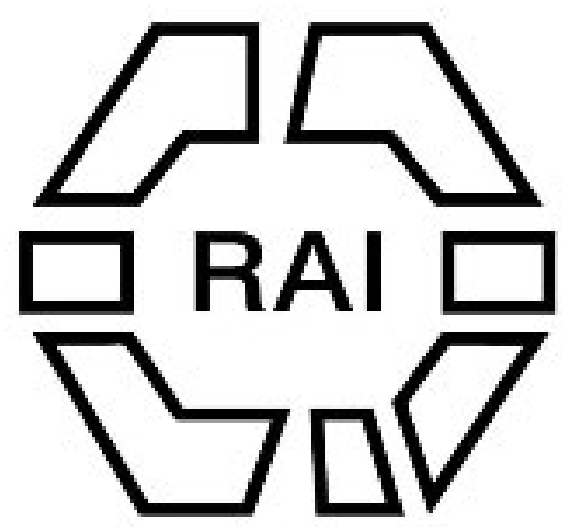

A Genealogical Method of Collecting Social and Vital Statistics Author(s): W. H. R. Rivers

Source: The Journal of the Anthropological Institute of Great Britain and Ireland, Vol. 30 (1900), pp. 74-82

Published by: Royal Anthropological Institute of Great Britain and Ireland

Stable URL: http://www.jstor.org/stable/2842619

Accessed: 15/06/2014 16:53

Your use of the JSTOR archive indicates your acceptance of the Terms \& Conditions of Use, available at http://www.jstor.org/page/info/about/policies/terms.jsp

JSTOR is a not-for-profit service that helps scholars, researchers, and students discover, use, and build upon a wide range of content in a trusted digital archive. We use information technology and tools to increase productivity and facilitate new forms of scholarship. For more information about JSTOR, please contact support@jstor.org. 


\section{A GENEALOGICAL METHOD OF COLLECTING SOCIAL AND VITAL STATISTICS.}

By W. H. R. Rivers, M.A., M.D.

[Presented April 24tit, 1900، With Plates II and III.]

WhEN in Torres Straits with the Anthropological Expedition which went out from Cambridge under the leadership of Dr. Haddon, I began to collect the genealogies of the natives with the object of studying as exactly as possible the relationship to one another of the individuals on whom we were making psychological tests. ${ }^{1}$ I soon found that the knowledge possessed by the natives of their families was so extensive, and apparently so accurate, that a complete collection of the genealogies as far back as they could be traced would be interesting and might enable one to study many sociological problems more exactly than would be otherwise possible, and with the stimulus of Dr. Haddon's encouragement I collected in Murray Island and Mabuiag genealogies which included the families of almost, if not quite, every individual now living on those islands. It is only, however, since leaving the islands, and while getting the data into order, that I have realised the many possibilities which I believe this method opens to the anthropologist.

Two genealogies are given as specimens. The Murray example (Pl. II) is complete so far as I was able to make it. The Mabuiag example, on the other hand (Pl. III), is only part of a complete family; Maku was married twice, and this genealogy gives his descendants by one of his two wives.

In both genealogies the descendants in the male line only are given; those in the female line are given in the families of the husbands to which the numbers given in brackets refer, thus in the Murray genealogy the descendants of Soroi and Gaum will be found in genealogy No. $65^{2}$ giving the family of Soroi.

The names of the males are given in capitals and are always placed to the left of their wives', whose names are given in small type. The names in red in the Murray Island genealogy refer to the villages to which the individuals belonged; while in Mabuiag the names in red small type refer to the Augods (totems), and those in red capitals to the place to which an individual belonged, in the case of marriage outside the community.

The letters d.y. and d.unm. signify "died young" and "died unmarried" respectively.

The names which are underlined are those of individuals now living.

1 See Journ. Anthrop. Inst., N.S., vol, ii, p. 219, 1899.

2 The numbers given in these cross references refer to the numbers of the genealogies as I have them arranged at present. In the future complete publication of these genealogies this arrangement will probably be altered, and the numbers would therefore not correspond with those given here. 
In Murray Island, where it was rarely possible to go back more than two or three generations, I have collected nearly seventy families. In Mabuiag, on the other hand, where one could trace farther back, the genealogies run into one another much more and are consequently fewer in number. In the Mabuiag genealogy it will be noticed that each family has more than one totem. These run through the whole clan.

The method of collecting the data may first be described. In Torres Straits, as in so many other parts of the world, the system of kinship is so wholly different from that of ourselves that many of our simplest terms of relationship cannot be used without the danger of great confusion and error.

In collecting the genealogies $I$ therefore limited myself to as few terms as possible, and found that $I$ could do all that was necessary with the five terms, father, mother, child, husband, and wife. Care had of course to be taken to limit these terms to their English sense. The term which was open to the most serious liability to error was that of father, but I was able to make the natives understand very thoroughly that I wanted the "proper father."

I took one individual as the starting-point of a genealogy, found the name of his real father and mother, then if either had been married more than once; then the names of their children in proper order and ascertained the marriages and fanilies of each child. Thus in drawing up the Murray genealogy, my startingpoint was Wam, the mother of Pasi, my informant. After having ascertained the descendants of $\mathrm{Iu}$ and Wam, given in genealogy No. 13, I asked the proper father and mother of Wam, ascertaining that each had only been married once. The children of Gasari and Koni were then given in order. Wam's descendants being already known and Maiwas not having married, I only had to ascertain the descendants of Charlie.

When these were exhausted, I returned to Gasari and inquired the names of his proper father and mother, the names of their children in order, the marriages and descendants of Kebar, and so on, till all the descendants of Tagai had been given.

There were some interesting differences in the mode of collection in the two islands, which were probably due to the greater extent to which the natives of Mabuiag have come into contact with civilisation. In Murray Island it was necessary to conduct operations with more or less secrecy, and to go away with one, or at most two, individuals to a spot where there was no chance of being overheard. This secrecy was always preferred by the natives of Murray Island when talking about any of their customs, but was probably rendered more necessary in this case by the penalties attached to the utterance of the name of a relation, or, at all events, of a wife's relation. It will be readily seen that any given family would come into several different genealogies, thus the family of Wasalgi and Olai in the Murray genealogy was not only obtained from Pasi in this case but also from Azao when giving the family of his wife, and

"In Torres Straits, all the younger men knew "pidgin" or "trade English." When working with some of the old men, one of the younger men would act as interpreter. 
from other sources, and one of the advantages of the secrecy necessary in Murray Island was that nearly erery detail of these genealogies was obtained from two or more independent sources, with the result that different accounts corroborated one another to an extent which forms the best guarantee of the truthfulness and accuracy of memory of the natives. There would be occasional discrepancies in such details as the exact order of birth of several children, the omission of a child who died young, and rarely the omission of a childless marriage, but on the whole the agreement between different accounts was extraordinarily close.

In Mabuiag the conditions were different. The secrecy required in Murray Island was here completely unnecessary. I often compiled my genealogies sitting in the huts, or on the sand, with a crowd of women and children sitting round listening to the information which the men were giving me. In some cases, even, the women were consulted. Often I was able to get several of the older men together, who consulted about points of detail, and it was obvious that some were looked up to by the rest as authorities on the subject. In Mabuiag I cannot therefore bring forward, as evidence of the trustworthiness of my genealogies, the same degree of independent corroboration as in Murray Island, but the close corroboration of accounts obtained on different occasions and the general consistency of the whole collection furnish conclusive evidence of their essential accuracy. Independent corroboration has recently come from Mabuiag. Waria, the present Mamus (or chief) of Mabuiag, who was one of the chief helpers of the expedition, was so impressed by the interest taken in the families of his people that he has drawn up an independent account of the genealogies of the island. Mr. Cowling, who lives in Mabuiag, has written out Waria's account, and has very kindly sent it to me, so that I have been able to compare his account of the genealogies with my own. In all essential points the agreement is very close, minor discrepancies being of the kind that I have already mentioned. Waria has also given a complete account of some families for which my clata were only fragmentary, and the book sent me by Mr. Cowling will enable me to make the whole scheme of the Mabuiag genealogies very complete.

In Murray Island adoption was very common, and I cannot be certain that I have altogether avoided the errors due to the prevalence of this custom. A child was often adopted in the first few days of life (the adoption might be arranged before the birth of the child), and it was said that there were cases in which individuals had grown up, married, and died without ever learning their real parentage. I was aware of this, and was, in consequence, always careful that at least one of my informants in any given genealogy should not be closely connected with the family in question.

Mr. Bruce, who lives on Murray Island, has been collecting information for Dr. Haddon on various points since we left the island, and is inclined to be despondent as to the possibility of distinguishing between the real and the adopting father, At the same time, however, Mr. Bruce has sent some evidence 
which supports the correctness of my genealogies in this respect. Two lawsuits, dealing with the disputed ownership of land, have recently been tried before the court in Murray Island. ${ }^{1}$ These cases turned on the question of adoption and on the real parentage of two men. In each case several witnesses were called and the real parentage clearly established. On referring to my genealogies, I found that in each case my account of the parentage of the men in question is correct. One of these men, Olmek or Meiti, was an adopted son of Nau in the genealogy in Pl. II, and had inherited some land from Nau. Olmek had died, Nau's own children had left no heirs, and Tanu, as the next representative of Nau, had brought an action to recover the land from Olmek's widow. It was decided that Olmek was the adopted son of Nau, but nevertheless the right of his widow to the land was upheld. ${ }^{2}$

In these cases the real parentage of two individuals has been decided as definitely as such a question can ever be decided, and it is satisfactory that in each case my data have turned out to be correct. Nevertheless, it is quite possible that I have included adopted children in some families, but there is no doubt that, if this be so, the adopted child in such a case has become an integral part of the family, so that for many of the statistical purposes to which these genealogies may be put their value would not be affected.

In Mabuiag, so far as I could find, adoption was much less common, although I have accounts of several cases. The chief difficulty in this island arose from the custom of exchanging names. A man would exchange names several times during his life and would be called sometimes by one name, sometimes by another. In some cases not only would a man exchange names with another man, but their wives and children would exchange names at the same time, and in collecting my genealogies I would sometimes come across a man, wife, and child with exactly the same names as others in an altogether different family, leading me at first to suppose that, in one case or the other, my information must have been wrong, and it was often only after considerable investigation that I was able to establish the identity of different individuals.

Having shown that extensive genealogies can be collected among savage communities which possess a high degree of accuracy, I may now point out some of the uses to which they may be put in the exact study of sociological problems, and in the collection of social and vital statistics. I have not yet drawn up any complete statistics because I am hoping to make the genealogies still more complete by the addition of some details about which I am making inquiries from Mr. Bruce on Murray Island and Mr. Cowling on Mabuiag.

The first and most obvious value of the genealogies is that they enable one to study the systems of kinship very thoroughly. I have a large amount of material

1 When we were in Murray Island, the court consisted of the Mamus (chief) of Murray Island and the Mamus of Dauar, with Mr. Bruce as an assessor, Since we left the island, a council of four natives has been added.

These cases will be published in full in the Reports of the Expedition. 
giving the names of relationship which given individuals apply to other members of their community, and shall be able to give the exact equivalents of these in English terms of relationship. It will be possible to work out the system of kinship with a degree of definiteness which would not otherwise be possible. I need only say here that in both islands the system of kinship is of the kiud known as "classificatory," and that the systems of the two islands present certain interesting differences.

The genealogies provide a large amount of material bearing on marriage customs. Dr. Haddon has described ${ }^{1}$ the existence in the western tribe of Torres Straits of four intermarrying groups. The islands of Mabuiag and Badu together form one of these groups, and the genealogies show very clearly that the vast proportion of marriages take place between the natives of these islands who form one community in respect of marriage. Marriages out of the community are, however, not uncommon, and the data of the genealogies will give in statistical form the relative frequency of these marriages and the islands with which marriages of this kind most frequently occur.

In Murray Island, again, the vast majority of marriages will be shown to take place within the island and with natives of the two small adjacent islands of Dauar and Waier. ${ }^{2}$ It will be shown, however, that marriages with natives of Erub or Darnley Island are not uncommon, and that occasionally marriages have taken place with natives of other islands. Similarly the frequency of marriages with members of other races will be shown.

Within the intermarrying communities, the genealogies will show very clearly the dependence of marriage in Mabuiag and Badu on the totemistic system. Individuals of the same clan do not marry one another. Among the Australians we know that not only is this the case, but a man of one clan must marry a woman of another given clan; a Cicala man must marry a Crow woman, and a Crow man must narry a Cicala woman. There is no distinct evidence of the existence within recent times of such a custom in Mabuiag, but it is probable that the statistics derived from the genealogies will show a tendency in this direction. Rough inspection of most of the genealogies shows that there is a tendency for certain clans to marry into one another, and when the genealogies are completed, une will be able to show the relative frequency with which individuals of one clan marry individuals of the other clans of the community.

In Murray Island, on the other hand, the genealogies will show that marriagcs are regulated by the places to which the natives belong. A man cannot marry a woman of his own village or of certain other villages. The totemistic system which probably at one time existed in this island appears to have been replaced by what may be called a territorial system. Here, anain, the statistics of the marriages will show if there is any special tendency for certain villages to intermar'y.

1 Jontu. Anthrop. Inst., xix, 1890, p1. 301, 353, 356 .

" The people of these islands now live on Munay Island. 
The genealogies show that polygamy existed till quite lately in both Murray Island and Mabuiag. On the latter island in one case a man still has iwo wives living, though one has been discarded owing to missionary influence. The custom, however, appears to have been exceptional. In some of the cases of polygainy two or more of the wives were sisters, and in the absence of polygamy it was still common for a man to marry his deceased wife's sister. In the Mabuiag genealogy, the two wives of Nobua, viz., Pad and Swopei, were own sisters, and Panai and Gugui, the two wives of Iwau, were sisters according to the native system of kinship, though first cousins according to ours.

Another marriage custom which existed with polygamy, and will be shown by the genealogies to have been of frequent occurrence, is a form of the levirate. In the old days a man took his brother's widow in addition to any wife or wives he might already have, and even when he had only one wife, she was in many cases the widow of his brother. In the Mabuiag genealogy, Iwau's second wife, Gugui, was the widow of Madui, Iwau's younger brother. Azigo, the wife of Gaulai, was the widow of Waup, who was Gaulai's second cousin according to our system of kinship, but Gaulai's brother according to that of the island. The marriage of Moipi, the widlow of Wap, with Per was probably of the same kind, but I am not at present certain of the exact relationship of Wap and Per.

Another very common custom which continues to the present day is that brother and sister should marry sister and brother. In the Mabuiag genealogy this was the case with two of the children of Maku; Umu, the wife of Paitu, was halfsister (by the same father) to Kadi, who married Kiesu, Paitu's sister.

Another instance occurs in the next generation; Gebi, the first wife of Gemini, was own sister of Uwaga. Another instance in the present day is in the case of Gizu's wife, Mudulpur, who was own sister of Iwau, who married Gugui, Gizu's sister. Gugui is thus an example of three different customs; she was the sister of her husband's previous wife, the widow of her husband's brother, and married the brother of her brother's wife.

In Murray Island, also, the same custom existed, and in the genealogy given the marriage of Tanu and Saiop, and of Barsa and Akoko, are examples of the custom. A recent marriage in Murray Island was delayed for some time because the bridegroom had not a sister to become the wife of the bride's brother.

All that can be done in the present paper is to point out the existence of these marriage customs ; the statistics derived from the genealogies will show their relative frequency and will, I hope, help to elucidate the relation of these various customs to one another.

Before leaving the subject of marriage, I may give one instance which shows the value of the genealogical method as a means of discovering facts which direct inquiry failed to elicit. In spite of the certainty of the natives that a man never married a woman of the same clan, I met with instances in which a Dangal (dugong) man had married a Dangal woman. When I pointed this out to my informants at Mabuiag, I altogether failed to get any explanation, although I 
returned to the subject repeatedly, and I was inclined to believe that these cases, which according to the expressed views of the natives would be cases of incest, were evidence that the totemistic system was breaking down. It was in favour of this view that all the cases were comparatively recent. It is only lately, on working up the genealogies, that I have found that in these cases the secondary totems were different, thus a $\left.\begin{array}{l}\text { Dangal } \\ \text { Kodal }\end{array}\right\}$ man has married a $\left.\begin{array}{l}\text { Dangal } \\ \text { Gapu }\end{array}\right\}$ woman. We do not at present understand the significance of these secondary totems in Torres Straits, but there is little doubt that in this special case we have to do with separate clans, each having the dugong as its chief totem, and it is significant in

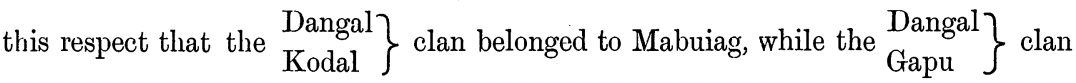
belonged to Badu.

The genealogies will illustrate other features of the totemistic system, in addition to those connected with marriage, which have already been considered. They will show very clearly, for instance, the descent in the male line, and the transmission of the secondary totems through the whole clan. Dr. Haddon has collected a number of facts which point towards a grouping of the totems of Mabuiag, and it has been seen that the marriages probably show something of the same kind, and I hope that the marriage statistics will furnish material which will help Dr. Haddon to clear up the meaning of this grouping. The significance of the secondary totems is another problem on which it is to be hoped that the genealogies will throw some light.

The social customs connected with names form another group which will be very largely illustrated by the genealogies. It will, for instance, be very clearly shown that there was in Torres Straits no trace of a "tabu" on the names of the dead. Names often recur in different generations, and several instances occur in which, one child having died, the next child of the same sex has been given the same name. ${ }^{1}$ An extreme example of the absence of this "tabu" is the case of a woman named Salmui. This is probably a man's name and was the name of this woman's father. He was drowned shortly before the birth of this daughter, and his name was given to the posthumous child notwithstanding the sex. Such a case shows not merely the absence of a "tabu," but a very decided preference for perpetuating the name of the dead.

Numerous other interesting points in connection with names will.also be brought out by the genealogies, such as the characters of male and female names, the relation between the names in Murray Island and Mabuiag, etc.

The subjects so far considered come under the heading of social statistics.

The special problems which come under the heading of vital statistics include the average size of families, the proportion of the sexes, the proportion of children

1 In the Murray Island genealogy there is an instance of this; the firstborn of Charlic and Kaibor was named Kuliar, and died in infancy. While we were in Murlaty Island twius were born, and the elder received the same name. This child also died when a few weeks old. 
who grow up and marry to the total number born, the proportion of the sexes who grow up to adult life, etc. The genealogies will furnish a large mass of material on these subjects, and it may even be possible to obtain some idea of differences in these respects in different generations.

A question of very great biological interest, on which the statistics may throw some light, is that of the relative fertility of different classes of marriage. From the biological point of view, the marriages in Torres Straits may be divided into three groups, viz., mairiages within the island or intermarrying group, marriages out of the island or intermarrying group, but with members of the same race, and marriages with members of other races. In the first group there is a large amount of intermarriage, although much controlled by the marriage customs, thus in Mabuiag marriages with a second cousin, or second cousin once removed through the female line, were common, and it was very difficult to find anyone in either Murray Island or Mabuiag to whom a given native would not apply some term of relationship. It will, therefore, be interesting to compare the fertility of these marriages with others in which new blood has been introduced from outside, and the genealogies will probably enable one to do this in a sufficient number of cases to justify some definite conclusions. It is worth noticing here that Maku in the Mabuiag genealogy, who has probably more lineal descendants on Mabuiag than any other man, married two wives from Boigu and Dauan respectively. The natives of these islands are of the same race as those of Mabuiag, but belong to a different intermarrying group.

During the last twenty or thirty years a large number of marriages have taken place with members of other races, especially with Melanesians, from the Loyalty and New Hebrides Groups. There have also been a fair number of marriages with Polynesians. In collecting the genealogies I was struck by the frequency with which these marriages were childless, and I have little doubt that when the statistics are worked out they will show that fewer children were born to such marriages than to those between members of the same race. If such a fact could be established, it would have great biological interest, but I am afraid that, in this case, there are disturbing factors. Many of the marriages were only of a temporary nature, terminating on the return of the husband to his own home. We know also that abortion was practised in Torres Straits, and it is possible that this practice may have been adopted more commonly in these than in ordinary marriages. The conditions are too complex to allow any confident generalisation without more definite knowledge than we possess.

While collecting the genealogies, I was frequently informed of various interesting facts in the lives of the people whose names occurred, and I believe that it would be possible to write a full and fairly accurate account of the recent history of a savage community by taking a complete genealogical record of the community as a concrete background. One of the chief sources of the vagueness which too often characterises the accounts of historical events obtained from savages is the indefiniteness of their ideas of time, and the genealogical details

Vor. XXX (N.S. III). 
would give definiteness to the narrative and serve the same purpose as dates in the history of civilised communities.

All who have experience of the savage mind must have experienced the difficulty of eliciting information on abstract questions, while, on the other hand, there seems to be hardly any limit to the number of concrete facts which can be remembered. The menory of the savage for names is as highly developed as in any European, and far more so than in those Europeans who are accustomed to abstract thinking. The great value of the genealogical method is that it enables one to study abstract problems, on which the savage's ideas are vague, by means of concrete facts, of which he is a master. It is a means of utilising the store of information which the extraordinary memory for detail of the savage has enabled him to accumulate.

The object of this paper is to bring before the members of the Institute an anthropological method, and I have merely sketched some of the problems which this method may help to solve. The statistics based on the genealogies of Torres Straits will, I hope, supplement the sociological material collected by Dr. Haddon, to whom I am glad of this opportunity of expressing my great indebtedness.

\section{Discussion.}

Dr. JAPP, having complimented Dr. Rivers on the results of his very extensive labours and his excellent system of tabulation, which reduced most complicated phenomena to comparative simplicity, ventured to ask whether in the case of "interchange of sisters," referred to by him as existing among the people he was dealing with, there was anything in the least corresponding to what was common among the Gallas of East Africa. A young man there desirous of "exchanging sisters" with another, but, having no sister, would embrace the first opportunity to go to war or on raid to procure a female captive. Having first with all due formalities initiated her into the clan or tribe, the young man would then exchange her as a sister with his friend for his sister to become his bride. Dr. Japp remarked further that a noticeable peculiarity in this case was that the origin of these Gallas had caused much discussion among anthropologists, who declared that they were certainly not pure negroes, others again asserting that they presented proofs of really tracing to a white or a yellow race, and that they practised nothing like purchase, pure and simple, in marriage.

Dr. RIVERs said there was, so far as he knew, nothing corresponding to this in the case of the tribes he had dealt with. 


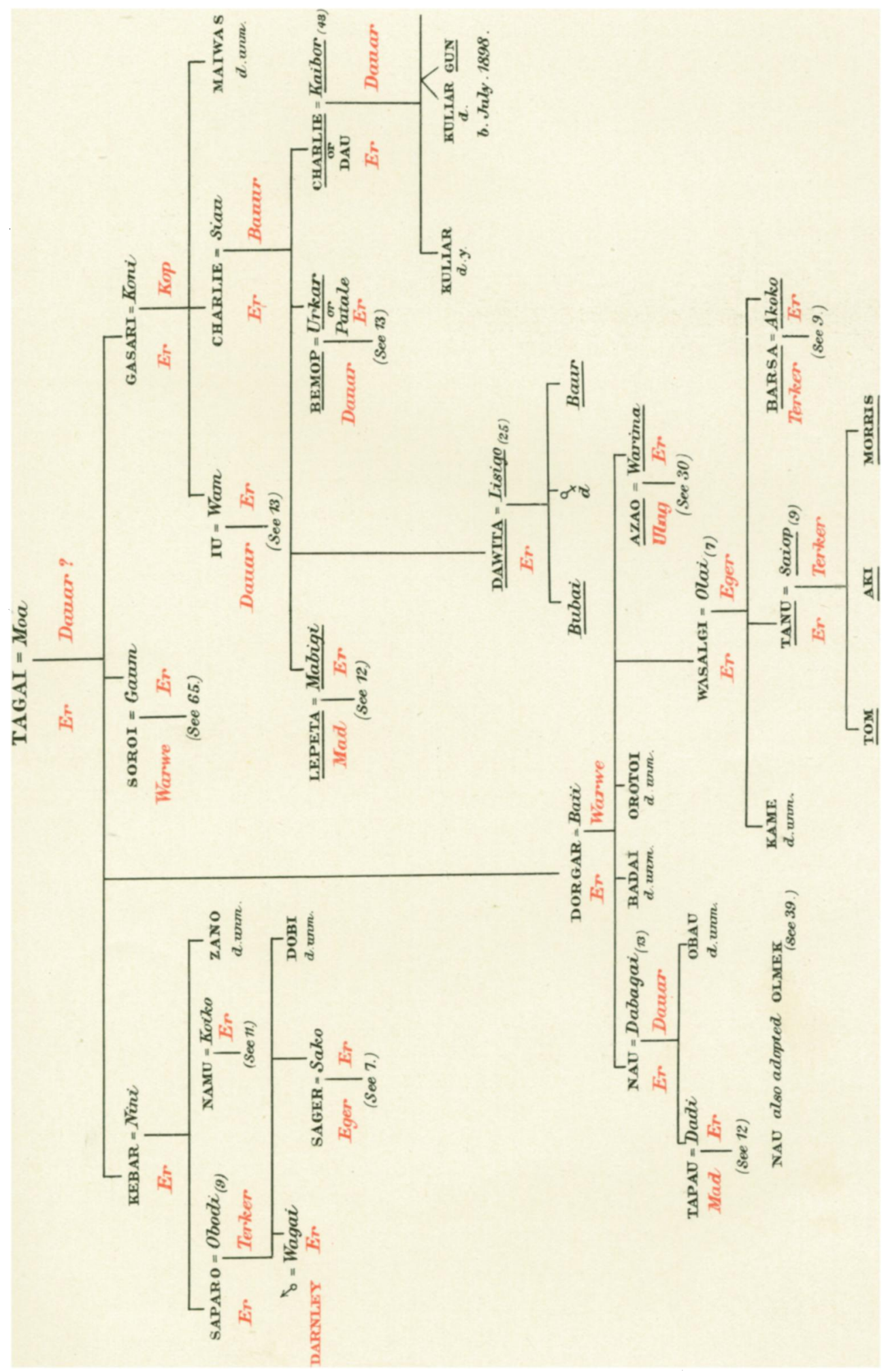




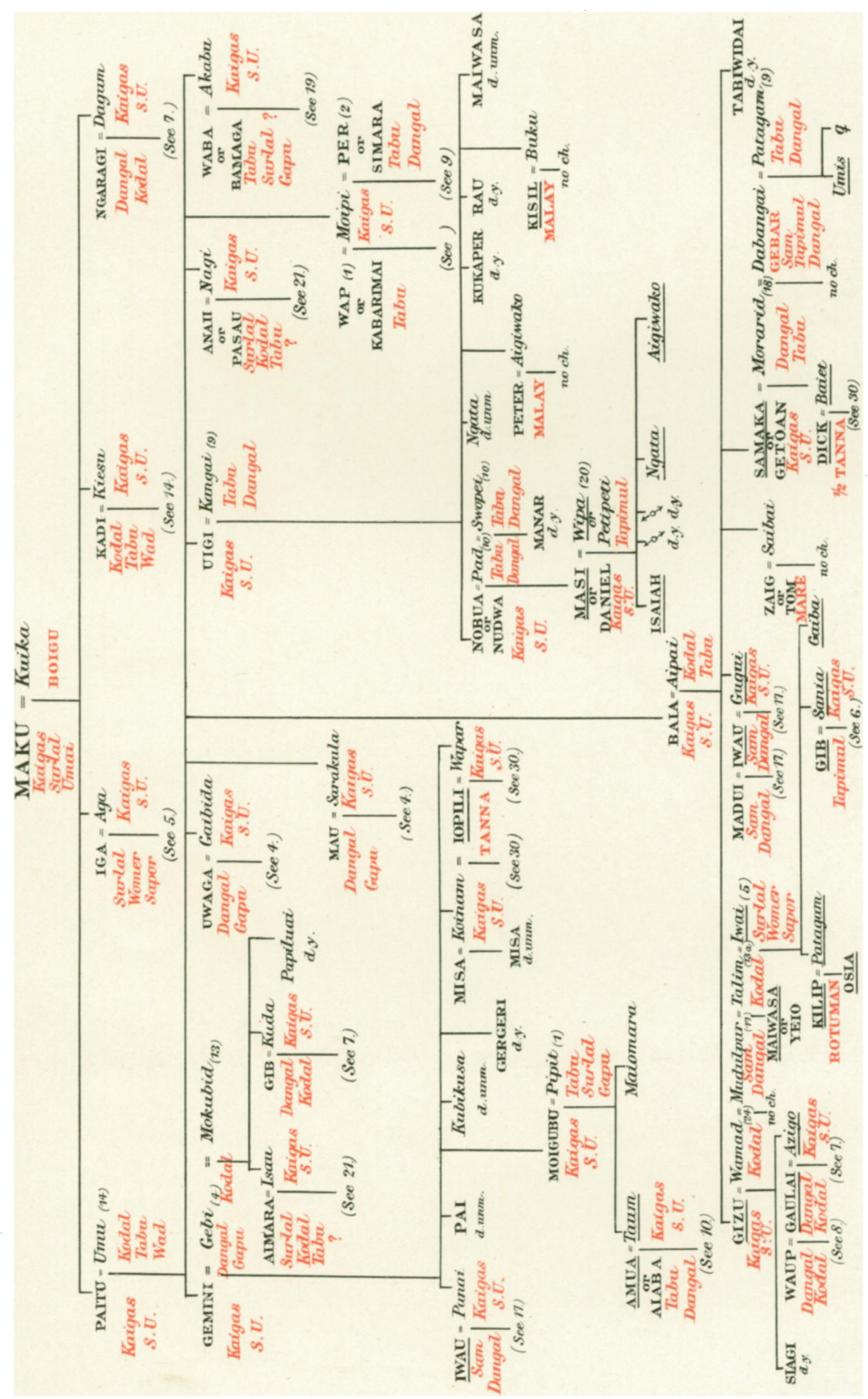

